\title{
Lignocellulosic residues for production of electricity, biogas or second generation biofuel: A case study of technical and sustainable potential of rice straw in Mali
}

Nygaard, Ivan; Dembelé, Filifing ; Daou, Ibrahima ; Mariko, Adama; Kamissoko, Famakan; Coulibaly, Nanourou; Borgstrøm, Rasmus L.; Beck Bruun, Thilde

\section{Published in:}

Renewable \& Sustainable Energy Reviews

Link to article, DOI:

10.1016/j.rser.2016.03.023

Publication date:

2016

Document Version

Peer reviewed version

Link back to DTU Orbit

Citation (APA):

Nygaard, I., Dembelé, F., Daou, I., Mariko, A., Kamissoko, F., Coulibaly, N., Borgstrøm, R. L., \& Beck Bruun, T. (2016). Lignocellulosic residues for production of electricity, biogas or second generation biofuel: A case study of technical and sustainable potential of rice straw in Mali. Renewable \& Sustainable Energy Reviews, 61, 202-212. https://doi.org/10.1016/j.rser.2016.03.023

\section{General rights}

Copyright and moral rights for the publications made accessible in the public portal are retained by the authors and/or other copyright owners and it is a condition of accessing publications that users recognise and abide by the legal requirements associated with these rights.

- Users may download and print one copy of any publication from the public portal for the purpose of private study or research.

- You may not further distribute the material or use it for any profit-making activity or commercial gain

- You may freely distribute the URL identifying the publication in the public portal 


\section{POST PRINT VERSION}

of paper accepted for publishing in

Renewable and Sustainable Energy Reviews, 61 (2016) 202-212

Title: Lignocellulosic residues for production of electricity, biogas or second generation biofuel: A case study of technical and sustainable potential of rice straw in Mali.

\section{Athor names and affiliation:}

Ivan Nygaard (corresponding author)

UNEP DTU Partnership, Department of Management Engineering, Technical University of Denmark, UN-City, Marmorvej 51, 2100 Copenhagen Ø, Denmark.

E-mail: ivny@dtu.dk, Phone: +45 45335297.

Filifing Dembelé

Rural Polytechnique Institute for Training and Research (IPR/IFRA), Mali.

Email: filifingdem@yahoo.fr

Ibrahima Daou

Rural Polytechnique Institute for Training and Research (IPR/IFRA), Mali.

Email: ibrahada2@yahoo.fr

Adama Mariko

National Engineering College (ENI/ABT), Mali

Email: Adama.Mariko@ird.fr

Famakan Kamissoko

Renewable Energy Agency (AER- Mali)

Email: kmakan200298@yahoo.fr

Nanourou Coulibaly

Renewable Energy Agency (AER- Mali)

Email: coul.nkm5@gmail.com

Rasmus L. Borgstrøm

DHI GRAS A/S, Agern Allé 5, 2970 Hørsholm, Denmark

Email: rlb@dhi-gras.com

Thilde Beck Bruun

Department of Plant and Environmental Sciences, University of Copenhagen, Denmark. Email: thbb@plen.ku.dk 


\begin{abstract}
:
Biomass from agricultural residues, especially lignocellulosic biomass, is not only seen as a sustainable biomass source for the production of electricity, but increasingly as a resource for the production of biogas and second-generation biofuel in developing countries. Based on empirical research in an irrigated rice-growing area, Office du Niger, in Mali, this article builds scenarios for the sustainable potential of rice straw. The paper concludes that there is great uncertainty regarding the size of the sustainable resources of rice straw available for energy, but that the most likely scenario estimates a resource of about 120,000 tonnes, which would permit up to three $5 \mathrm{MW}$ rice straw-fuelled power plants. Based on the findings from the empirical studies, the article further suggests that recently published research on the potential of rice straw in a number of African countries seems first to underestimate the uncertainty of resource assessments, and secondly to overestimate the resources available for energy production, mainly due to optimistic residue-to-product ratios and availability factors.
\end{abstract}

\title{
Keywords:
}

Biomass resources; rice straw; lignocellulosic residues; second generation biofuel; renewable energy; Mali 


\section{Introduction}

Biomass from agricultural residues, especially lignocellulosic biomass, is not only seen as a sustainable biomass source for the production of electricity [1-3] but increasingly as the resource for the production of biogas and second-generation biofuel in developing countries [4,5]. In this regard, a number of studies of available biomass for energy have been produced at the global level [6,7], for Europe (see e.g. [8], and for the African continent [9,10]. Common to the global and EU studies is the fact that methodologies are difficult to compare and that the results vary significantly from low to high predictions.

With regard to the African continent, a number of country studies of biomass potential have recently been published [11-18]. These studies generally report on a number of different biomass types selected according to their importance in terms of availability. Often the analyses comprise all available biomass residues and waste streams $[11,13,16,19]$, while in a number of cases they provide only partial analyses, mainly concentrating on agricultural residues [12,14,17], agriculture and forestry residues [15], or dedicated energy crops [18]. While global studies and EU studies often look forward to 2030 or 2050, national studies in Africa in general provide only static analyses based on FAO crop-production statistics, global residue-to-product ratios and global assumptions regarding available shares of the resource.

To refine and consolidate the parameters for global and regional studies, there is a need for localized, empirically based studies which take into account the spatial distribution and competing use of biomass resources, as well as providing scenarios for future prospects. The current case study from Mali contributes to fill this gap by providing a first estimate of the potential sustainable resources of rice straw in Office du Niger in Mali. It addresses the methodological challenges involved in assessing the technical and the sustainable resources of lignocellulosic biomass, as well as the uncertainties of biomass resource estimates.

The article starts by briefly describing the farming practices in the case study area. Section 3 describes the methodology used in the study, including the conceptual framework and the assumptions behind the scenarios defined. The results of the study are presented in Section 4, and the uncertainties and limitations of the study are discussed in Section 5. Before providing a conclusion in Section 7, Section 6 discusses the potential implications of the findings for interpreting existing research and provides recommendations for future research. 


\section{Farming practices in Office du Niger}

In this article, Office du Niger (ON) is used as a case study for the assessment of sustainable resources of rice straw in Mali because it is the most important ricecultivating area in Mali and the area with the highest concentration of rice straw. This section will provide the context for the study, including the historical background to rice production in $\mathrm{ON}$ and a short description of current agricultural practices.

ON was founded in 1932 as a colonial-owned entity based on forced labour with the objective of supplying the French colonial power with cotton. Plans were ambitious, aiming to develop almost one million hectares (ha) [20]. ON started by producing cotton, but this was gradually abandoned in 1965-1970 when rice was introduced. However, already by the end of the 1970s, the production of rice was decreasing and the equipment and infrastructure had fallen into decay, whereupon the World Bank and a wide group of donors engaged in a large rehabilitation programme [21]. Dramatic economic and institutional changes accompanied technical and financial support for the rehabilitation of infrastructure such as canals, drainage systems etc., . In the years from 1986 to 1994, ON's trade monopoly on rice and fertilizer was abolished, village associations were made responsible for water management, and central threshing and hulling were gradually replaced by decentralised and privatized threshing and hulling. The effects were impressive: in the period from 1979 to 1994 the yield of rice increased by $300 \%$, a development that is continuing, as will be further explained below [22]. ON is currently a dynamic agricultural development area in Mali, which is still attracting a high level of donor intervention and recently also large-scale private investment [23,24].

In spite of recent developments, however, the production of rice is still based on a high level of manual labour input. The rice is harvested by sickle and left in the field to dry. From there it is manually transported to the dikes, where it is stored in piles until it is threshed by mobile threshers. Due to problems with water management and drainage, the rice fields are often still wet during the harvest, making the mechanization of harvesting and the transport of straw from the fields difficult [25]. Currently the stubble left in the fields is partly burned, partly incorporated into the soil and partly used to feed grazing animals.

The number of cattle in the $\mathrm{ON}$ is high, but statistical information is currently not available. In 1998 there were about 300,000 head of cattle (including 43,000 draught oxen) and about 16,000 donkeys for transport [26]. According to extension officers in the area, the number of cattle has increased since 1998. During the rainy season most of the cattle are on transhumance in the pastoral zones around the irrigated areas in ON, but the animals return to these areas during the dry season from December to May/June. During this period they graze stubble in the fields and feed on piles of threshed straw [26]. 
The cattle in the ON do not only belong to the farmers themselves. During the dry season the relative abundance of feed stock in the inland delta has traditionally attracted transhumant herders from the regions north of ON. The increasing pressure on fodder, partly due to decreases in rainfall, but mainly to increases in the number of cattle, means that the large irrigated area in $\mathrm{ON}$ is an attractive destination for transhumant herders with their cattle. The grazing of stubble by one's own and others' transhumant cattle is part of a long tradition of cohabitation between herders and farmers [27]. The manure left in the fields is a valuable source of organic fertilizer for the farmers, but the growing numbers of cattle in the region increasingly create tensions and conflicts between farmers and herders when transhumant cattle destroy crops $[28,29]$. These conflicts are also present in $\mathrm{ON}$ and have been further intensified by the widespread practice of bi-seasonal farming, comprising vegetable farming and short-cycle rice production. It is evident that cattle in this context can cause problems by destroying crops in cultivated fields, and some farmers now express a strong interest in the transhumant cattle being excluded from the irrigated area.

Burning straw in the fields is an old practice which has been strongly opposed by the agricultural extension workers from $\mathrm{ON}$ in order to reduce the risk of bush fires, reduce local air pollution and make use of the fertilizer value of the straw by incorporating it into the soil. The latter practice has been greatly encouraged by the agricultural extension services in the area. Nevertheless a considerable amount of straw is still being burned in the fields. According to interviews with farmers and extension workers, farmers mainly burn threshed straw to prevent it piling up on the dikes and fouling up the drainage system. A smaller amount of threshed straw is also burned to provide nutrients for vegetable gardening and for rice nurseries. Besides the threshed straw, the stubble is also burned in the fields to combat weeds and to ease cultivation of the next crop.

In spite of the high pressure on rice straw for cattlefeed, agricultural specialists and energy specialists in Bamako suggested in a preliminary mapping that ON was the most interesting place to assess agricultural residues for energy purposes, and to assess the feasibility for large-scale use of straw for electricity production [30-33]. A considerable amount of straw that was either being burnt or incorporated into the soil could therefore be available for energy purposes, although at a cost in terms of, for example, an increased use of fertilizer. The methodology used for this assessment is described in the next chapter.

\section{Methodology}

The present assessment of the technical and sustainable resources of rice straw for energy purposes is based on a combination of field studies, national statistics and a review of national plans, reports and international research. The field studies 
comprised 263 questionnaire-based interviews with local farmers about their current use of straw and semi-structured interviews with extension workers, management in ON and national experts about rice cultivation practices in Mali.

The first subsection defines how technical and sustainable resources should be understood in this paper. The following subsections conceptualize a simple model with which to calculate five scenarios for future resources of straw for energy purposes. The main parameters of the model, such as evolution in yields, residue-toproduct ratios (RPR), competing uses of straw and expected land-use change over time, are also described.

\subsection{Defining potentials}

The potentials of biomass for energy are often defined in terms of theoretical potential, technical potential, economic potential and implementation potential [7]. Sometimes a geographical potential, ecological potential [34] and sustainable potential [35] are added. These categories are not always defined in the same way, and some of them overlap. One recent study [36] groups the definitions into three main categories: i) theoretical, ii) technical, and iii) market (economic) potential. Within the three categories the author defines the ecological potential as a subset or limited part of the technical potential, and the implementation potential as a subset of the economic potential.

This article uses the concepts of technical potential and sustainable potential according to the definition outlined in [35]. In the Malian study they have been operationalized as follows:

The technical potential is defined as the amount of harvested and threshed straw at a given time. The harvested amount is calculated as the rice (grain) recorded in national statistics multiplied by an estimated RPR at a given time.

The sustainable potential is the fraction of the technical potential which can be extracted in an economically viable manner without causing social or ecological damage. In the Malian context, this is interpreted as the fraction which is currently being burned.

Other uses are mainly: i) feed for own cattle, ii) feed for others' cattle, including neighbours and cattle on transhumance, or iii) incorporation into the soil. Feed for cattle is considered so vital to the Malian herders that it would be socially and culturally unacceptable to use it for energy.

The impact of using the straw which is currently incorporated into the soil for energy purposes is less obvious. A study of the environmental impact of incorporating the 
straw into the soil indicates that using the rice straw as fuel would not have severe implications for the soil quality in the study area [37]. For one of the optimistic scenarios described further below, we have therefore included straw that is currently incorporated into the soil as part of the sustainable potential.

\subsection{Scenarios}

The sustainable resource of rice straw for energy will be described in the form of three main scenarios, the business as usual scenario, the realist scenario and four optimistic scenarios. The scenarios are based on a variation of parameters in a simple model, calculating the sustainable resource of straw for energy as:

Technical potential $=($ average yield $) *($ cultivated area $) *($ residue to product ratio, RPR $)$ Sustainable potential $=($ technical potential $) *($ availability factor $)$

The business as usual (BAU) scenario is based on the assumption that i) average yields, ii) cultivated area, iii) RPR, and iv) availability of straw remained unchanged from 2010 to 2020. The realist scenario is based on the assumption that about 50 percent of the planned increase in cultivated area will be achieved before 2020, and that yield will increase from 6.5 to 7.0 tonnes/ha. Other parameters remain constant. Each of the optimistic scenarios is based on the assumption that one of the factors yield, cultivated area, RPR or availability - will develop to a level that could be achieved under favourable conditions.

The following sections will provide a justification for the selection of each of the parameters, based on interviews, questionnaires, statistical information from government institutions, government and donor reports and the scientific literature.

\subsection{Average yield}

Rice yields have increased significantly since the 1980s due to e privatization of rice cultivation, the liberalization of the rice market, the availability of fertilizers and pesticides, and the introduction of new varieties. Average yields in ON rose from 1.6 tonnes/ha in 1982, to 4.5 in 1992 [38] and further to 6.5 tonnes/ha in 2010-2011. While this figure covers large variations, the national strategy for rice cultivation [39] expects that, with improved farming practices and the introduction of new varieties, the yield could reach 9-10 tonnes/ha. For the assessment, in 2020 we use 6.5 tonnes/ha for BAU, 7 tonnes/ha for the realist scenario and 8 tonnes/ha in for the optimistic scenarios. 


\subsection{Residue to product ratio}

The residue to product ratio (RPR) or straw to grain ratio is mainly dependent on the cutting height, the variety of rice, the soil quality and the fertilizer level [40].

According to the questionnaires, $68 \%$ of rice harvested in Niono, N'debougou and Molodo was of the GAMBIAKA variety, while the Adiny 11 and Wassa varieties covered $24 \%$. The last $6 \%$ was accounted for by other varieties. RPRs for the three main varieties were provided by $\mathrm{Mr}$ Yacouba Doumbia from the Institute Economie Rurale (IER). Based on this information, shown in Table 3.1, the weighted average of the RPR in ON was estimated at 0.63 .

Table 3.1. Share of rice production per rice variety in 2009 (questionnaires) and estimated $R P R$

\begin{tabular}{lccc}
\hline Variety & $\begin{array}{c}\text { Share of } \\
\text { production }\end{array}$ & RPR (interval) & RPR (mean) \\
\hline GAMBIAKA & $68 \%$ & $0.5-0.66$ & 0.58 \\
ADINY 11 & $12 \%$ & $0.6-0.9$ & 0.75 \\
WASSA & $12 \%$ & $0.6-0.9$ & 0.75 \\
BG & $3 \%$ & & 0.75 \\
SAMBALA MALO & $2 \%$ & & 0.75 \\
IER 32000 & $1 \%$ & 0.75 \\
NERICA & $0 \%$ & 0.75 \\
\hline Average & $100 \%$ & 0.63 \\
\hline
\end{tabular}

Most references to RPRs for rice straw can be traced back to field measurements in Thailand made for two different cases [41]. The first case corresponded to the normal 'high cutting' harvesting practice in Thailand at the time, where 'the rice straw contains the top portion of the rice stem with three to five leaves'. The second case reflected an alternative practice where the rice was cut 2 in. $(5 \mathrm{~cm})$ above the ground. The 'high cutting' case came up with values $(0.41,0.506,0.441)$ for three different varieties, and the 'low cutting' case came up with two different values (1.440 and 2.100) for two different varieties. Apparently based on the weighted average of the varieties at the time, the article estimates two values, 0.447 for 'high cutting' and 1.695 for 'low cutting'.

To estimate RPR we use the results of the two cases described by Bhattacharya et al. [41] as a guide to the range within which we should stay. For the BAU and for the realist scenario we retain a value of 0.75 , taking into account the average value calculated above in Table 3.1 based on existing high-cutting practice and the fact that the straw-to-grain value may increase when a straw-to-energy market is established. For the optimistic scenarios, we consider that practice will move further towards low cutting driven by an increased demand for straw. We therefore retain a value of 1.5 , lower than that suggested by Bhattacharya et al. [41], for low cutting, but adjusted 
down based on [40], which, although based on industrial rice production in California, is the best documented study available.

\subsection{Availability factor}

The current use of straw in ON was established through an interview-based survey comprising 263 questionnaires. The spatial stratification of the questionnaires was planned with a focus on three adjacent rice production zones around the town of Niono in ON, the target town for a pre-feasibility study of a straw-fired power plant [3]

The farmers were asked to estimate the share of their threshed straw that fell into the five categories. The results are calculated as a weighted average of use for each farm included in the interviews. The results of the survey, covering four selected zones in ON, are presented in Table 3.2.

Table 3.2. Current use of threshed rice straw in $O N$

\begin{tabular}{llllllll}
\hline Zone & $\begin{array}{l}\text { Inter- } \\
\text { views }\end{array}$ & $\begin{array}{l}\text { Burnt in } \\
\text { the field }\end{array}$ & $\begin{array}{l}\text { Incorpo- } \\
\text { rated into } \\
\text { soil }\end{array}$ & $\begin{array}{l}\text { Fodder } \\
\text { for own } \\
\text { cattle }\end{array}$ & $\begin{array}{l}\text { Fodder for } \\
\text { other } \\
\text { cattle }\end{array}$ & $\begin{array}{l}\text { Other } \\
\text { uses }\end{array}$ & Total \\
\hline Niono & $62 / 20$ & $22 \%$ & $11 \%$ & $31 \%$ & $35 \%$ & - & $100 \%$ \\
N'debougou & 61 & $19 \%$ & $10 \%$ & $12 \%$ & $59 \%$ & $0 \%$ & $100 \%$ \\
Molodo & 60 & $12 \%$ & $7 \%$ & $18 \%$ & $61 \%$ & $2 \%$ & $100 \%$ \\
\hline Kouroumari & None & $18 \%$ & $9 \%$ & $20 \%$ & $52 \%$ & $1 \%$ & $100 \%$ \\
Bewani & None & $18 \%$ & $9 \%$ & $20 \%$ & $52 \%$ & $1 \%$ & $100 \%$ \\
\hline Macina & 80 & $2 \%$ & $35 \%$ & $38 \%$ & $21 \%$ & $4 \%$ & $100 \%$ \\
\hline Weighted average & & $15 \%$ & $15 \%$ & $24 \%$ & $45 \%$ & $1 \%$ & $100 \%$ \\
\hline
\end{tabular}

The zones of Niono, N'debougou and Molodo were focused on, as they were closest to the potential site of the power plant. Macina was included in order to obtain a broader view of rice straw use, as it differs from Niono, N'debougou and Molodo in terms of being more prone to pressure from transhumant cattle. Kouroumari and Bewani, which are located north and south of the three zones mentioned above, are not included in the empirical study, but as they do not differ from these other zones in terms of agricultural practices, the average values for the latter are used as the best estimate. These figures are presented in Table 3.2.

\section{Availability factor}

For the sustainable resource in the BAU and realist scenarios, the availability factor used is equivalent to $15 \%$ of the straw that is currently burned in the fields. For the optimistic scenarios, the fraction currently incorporated into the ground is also included. This makes the availability factor for the optimistic scenario equal to $30 \%$. 


\subsection{Land use change}

In theory there are opportunities for significantly expanding the irrigated areas of rice and vegetable production in the ON, but recent studies show that, besides capital for investment, a limiting factor will be the availability of water for irrigation from the Niger River [25,42-45]. In 2004 the Malian government, in cooperation with a number of donor organisations, launched a master plan for development in ON, which is referred to as l'Etude du Schéma Directeur de Développement pour la Zone de l'Office du Niger, (SDDZON) [46] [47]. According to the master plan the cultivated area of 77,000 ha should be extended by 146,000 ha by 2020 , reaching in total 223,000 ha.

The overall potential, the cultivated area in 2004 and the planned expansion according to the master plan is shown in Table 3.3.

Table 3.3. Planned extension of the irrigated area in ON (hectares) [47]

\begin{tabular}{|c|c|c|c|c|c|c|}
\hline Chanel & $\begin{array}{l}\text { Hydraulic } \\
\text { system }\end{array}$ & $\begin{array}{l}\text { Geogra- } \\
\text { phical } \\
\text { area }\end{array}$ & $\begin{array}{l}\text { Agricul- } \\
\text { ture area }\end{array}$ & $\begin{array}{l}\text { Irrigated } \\
\text { area } 2004\end{array}$ & $\begin{array}{l}\text { Master Plan } \\
2005-2020\end{array}$ & $\begin{array}{l}\text { Theoretical } \\
\text { remaining } \\
\text { potential }\end{array}$ \\
\hline \multirow{4}{*}{$\begin{array}{l}\text { Depending on } \\
\text { 'canal du } \\
\text { Sahel' }\end{array}$} & $\begin{array}{l}\text { Kala } \\
\text { inférieur }\end{array}$ & 92129 & 73700 & 36244 & 36684 & 772 \\
\hline & Kouroumari & 139814 & 111900 & 14500 & 43475 & 53925 \\
\hline & Méma & 119476 & 95000 & 0 & 0 & 95000 \\
\hline & Farimaké & 124994 & 100000 & 0 & 0 & 100000 \\
\hline $\begin{array}{l}\text { Depending on } \\
\text { 'canal Costes' }\end{array}$ & $\begin{array}{l}\text { Kala } \\
\text { supérieur }\end{array}$ & 94738 & 75800 & 10722 & 26428 & 38650 \\
\hline \multirow{3}{*}{$\begin{array}{l}\text { Depending on } \\
\text { 'canal Macina' }\end{array}$} & Macina & 716610 & 573000 & 15712 & 39121 & 518167 \\
\hline & Kareri & 477327 & 382000 & 0 & 0 & 382000 \\
\hline & Kokeri & 142318 & 113800 & 0 & 0 & 113800 \\
\hline Total & & 1907406 & 1525200 & 77178 & 145708 & 1302314 \\
\hline
\end{tabular}

The planned extensions according to the master plan are illustrated in various ways in $[23,37,46,47]$. The master plan was adopted by the government (Conseil de Ministres) in December 2008, and although its implementation has been delayed for various reasons, the expectation at a donor conference in 2010 was still $78 \%$ of the projected extensions should be achieved by 2020 [46].

To illustrate the uncertainty and dynamics in land allocations and land use, it is worth mentioning that, in parallel with the development of the donor-supported master plan, the Malian government allocated about 550,000 ha outside the plan's limits to various national and international developers, mainly for oil-producing crops such as sunflower, soya, peanuts, shea-nuts and jatropha, and only to a limited extent to hybrid 
rice and wheat production. Among the foreign investors was the Libyan-based company, Malibia, which was granted about 100,000 ha for the production of hybrid rice, livestock and tomatoes [23,24].

\section{Land use change}

For the BAU scenario the cultivated area will be maintained at 77,000 ha in 2020. An estimate of 150,000 ha cultivated in 2020 is used for the realist scenario, being equivalent to a $50 \%$ implementation of the master plan, while the optimistic scenarios will use the 223,000 ha cultivated in 2020, according to the master plan.

\section{Results}

This section presents the results of the assessment of the sustainable potential of rice straw for energy in ON. Due to the high degree of uncertainty the results are presented as two main scenarios, a BAU and a realist scenario. Further four optimistic scenarios are presented to illustrate the uncertainties of the assessment.

\subsection{Business as usual}

For the business as usual scenario, the sustainable potential of straw for energy in ON is calculated on the basis of the average rice-grain yield in 2009 and 2010. The technical potential is defined as the amount of straw threshed and is calculated by using the uniform RPR of 0.75 for all zones. The sustainable resource is defined as the share of harvested straw which is currently burned. This share varies by zone and is estimated as described in Section 3.

Table 4.1. Technical and sustainable potential of straw for energy in ON (tonnes/year)

\begin{tabular}{lrrrrrrr}
\hline Zone & Macina & Bewani & Niono & Molodo & $\begin{array}{l}\text { Kourou- } \\
\text { mari }\end{array}$ & \multicolumn{2}{l}{$\begin{array}{l}\text { N'debou } \\
\text {-gou }\end{array}$} \\
& & & & & Total \\
\hline Avg yield. 2009-2010 & 105455 & 70153 & 85640 & 52081 & 104699 & 85522 & 503549 \\
RPR & 0.75 & 0.75 & 0.75 & 0.75 & 0.75 & 0.75 & 0.75 \\
Technical resource & 79091 & 52614 & 64230 & 39060 & 78524 & 64141 & 377661 \\
\hline Share being burned & $2 \%$ & $18 \%$ & $22 \%$ & $12 \%$ & $18 \%$ & $19 \%$ & $15 \%$ \\
Sustainable resource & 1582 & 9471 & 14131 & 4687 & 14134 & 12187 & 56191 \\
\hline
\end{tabular}

\subsection{Realist and optimistic scenarios}

The realist and optimistic scenarios for 2020 are only calculated for the entire ON. The main scenarios are the BAU and the realist scenarios, according to which 56,000 and 118,000 tonnes of straw respectively will be available for energy production in 2020. According to a pre-feasibility study reported in [3] a 5 MW electricity plant based on biomass combustion steam-cycle technology with the following 
caracteristics : Lower heat value for straw $=14.7 \mathrm{GJ} /$ tonne; average annual electric efficiency $=18.4 \%$; storage capacity for straw $=6$ month, number of full load equivalent hours $=6381$, would consume about 43,000 tonnes of straw. Therefore, the above mentioned resource of 118,000 tonnes in the realist scenario would allow for approximately three power plants rated at $5 \mathrm{MW}_{\mathrm{el}}$ each.

Besides these scenarios, four optimistic scenarios are presented in Table 4.2 and Figure 4.1. These are the result of an optimistic assessment of one of the parameters: area, yield, RPR, or availability. The available amount of straw for energy varies between 135,000 and 236,000 tonnes, or 2.4 to 4.4 times the amount in the BAU scenario. These scenarios show that the uncertainty relates to the cultivated area and the availability of straw for energy. The last column in Table 4.2 shows the superoptimistic scenario giving the available resource if all the optimistic parameters are fulfilled. In this case about 800,000 tonnes of straw would be available for energy, or about fourteen times the estimate in the BAU case.

Table 4.2. BAU, realist and optimistic scenarios for sustainable resources of straw for energy in $\mathrm{ON}$ in 2020

\begin{tabular}{|c|c|c|c|c|c|c|c|}
\hline Parameter & $\begin{array}{c}\text { Business As } \\
\text { Usual } \\
\text { (BAU) }\end{array}$ & $\begin{array}{c}\text { Realist } \\
\text { area/yield }\end{array}$ & $\begin{array}{c}\text { Optimistic } \\
\text { area }\end{array}$ & $\begin{array}{c}\text { Optimistic } \\
\text { yield }\end{array}$ & $\begin{array}{c}\text { Optimistic } \\
\text { PRR }\end{array}$ & $\begin{array}{l}\text { Optimistic } \\
\text { Availability }\end{array}$ & $\begin{array}{l}\text { Optimistic } \\
\text { all param. }\end{array}$ \\
\hline Cultivated area (ha) & 77,135 & 150,000 & 223,000 & 150,000 & 150,000 & 150,000 & 223,000 \\
\hline $\begin{array}{l}\text { Yield per ha } \\
\text { (tonnes) }\end{array}$ & 6.53 & 7.00 & 7.00 & 8.00 & 7.00 & 7.00 & 8.00 \\
\hline Total yield (tonnes) & 503,549 & $1,050,000$ & $1,561,000$ & $1,200,000$ & $1,050,000$ & $1,050,000$ & $1,784,000$ \\
\hline Straw to grain ratio & 0.75 & 0.75 & 0.75 & 0.75 & 1.00 & 0.75 & 1.00 \\
\hline Availability & $15 \%$ & $15 \%$ & $15 \%$ & $15 \%$ & $15 \%$ & $30 \%$ & $30 \%$ \\
\hline Straw total (tonnes) & 377,662 & 787,500 & ,170,750 & 900,000 & $1,050,000$ & 787,500 & $1,784,000$ \\
\hline $\begin{array}{l}\begin{array}{l}\text { Straw for energy } \\
\text { (tonnes) }\end{array} \\
\end{array}$ & 56,649 & 118,125 & 175,613 & 135,000 & 157,500 & 236,250 & 535,200 \\
\hline Optimist/BAU ratio & 1 & 2.09 & 3.10 & 2.38 & 2.78 & 4.17 & 9.45 \\
\hline
\end{tabular}

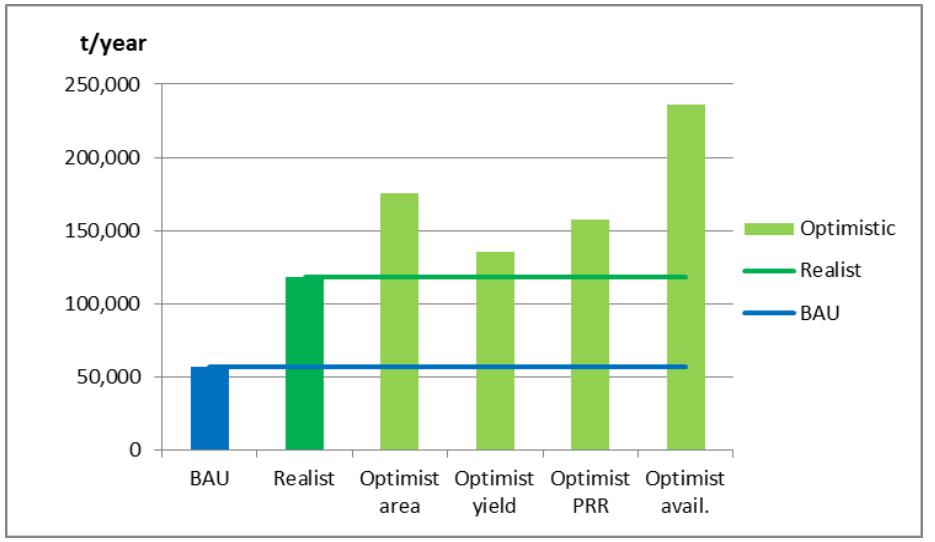

Figure 4.1. BAU, realist and optimistic scenarios for sustainable resources of straw for energy in $\mathrm{ON}$ in 2020 


\section{Uncertainty of sustainable resource estimates}

The scenarios presented in Table 4.2 and Figure 4.1 show a high degree of uncertainty regarding the sustainable amount of biomass available in 2020. The uncertainty is especially illustrated by the four optimistic scenarios, which for simplicity show the consequences of choosing an optimistic value for only one of the parameters in the model. Going from the BAU to the realist scenario, there is an increase of $100 \%$, but for each of the four parameters - yield, land use, RPR and availability - the increase from the BAU to the optimistic scenario is a factor of 3 and a factor of 4 , which again means that, going from the BAU to the super-optimistic estimate, there is a factor of 14. The methodology section has already provided the background for estimating the values for each parameter. This section will further discuss the uncertainties of the each of the parameters.

\subsection{Development in yield}

Development in yield is the parameter in the model which appears to be the least uncertain. This is first because statistics for the production of food crops are available as a long-time series for most countries from for example, the FAO. ${ }^{1}$ This makes estimating increases in yields relatively predictable. Secondly, especially in irrigated and intensively cultivated areas with relatively high inputs of fertilisers and pesticides, the current yield is at a level at which significant increases are not likely to occur within a short timeframe.

\subsection{Land use}

The uncertainty over future land-use changes in $\mathrm{ON}$ is an important parameter of the ability to assess future demand. In this case land-use change is driven by donorsupported efforts to support agricultural development in combination with land grabbing. The fall of the Libian leader, Muammar Gaddafi, in 2011 and the unstable political situation in Mali after the 'coup d'état' of March 2012 [48] is expected to have serious impacts on the future implementation of the donor-supported master plan, on the Libyan-financed Malibia project and on other foreign and national investments in the area. Future developments in cultivated areas are therefore considered to be highly uncertain, as indicated by the large range from the existing 77,000 ha being maintained or evolving to 150,000 ha (realist) or 223,000 ha (optimistic) in 2020, equivalent to $50 \%$ or $100 \%$ of the master plan being achieved.

1 http://www.countrystat.org/ 


\subsection{Residue to product ratio}

The uncertainty regarding RPR is very important for the results of the resource. To understand the validity of the existing data, we have conducted a systematic review of RPR used in recent scientific papers on biomass resources both in Sub Saharan Africa (SSA) and globally. The result of the review is presented in Table 5.1. The review shows first of all a very large variation in the RPRs applied in the papers, but also that most RPRs used in recent papers are to a very large extent based on the RPRs measured and reported by Bhattacharya et al. [41,49].

Looking at Table 5.1, it is remarkable that the lowest value is used for Thailand in two recent studies by Sajjakulnukit et al. [50] co-authored with Bhattacharya and referring back to Bhattacharya et al. [41]. The highest value (1.76) is used for Sri Lanka [51] a paper also co-authored with Bhattacharya and with reference to Bhattacharya's 1993 presentation at the FAO. As already mentioned in Section 4 above, these values reflect both high and low cutting practices. 
Table 5.1. Comparison of RPRs from various sources.

\begin{tabular}{|c|c|c|c|c|c|}
\hline RPR & Cutting & Country & Sourc & & First reference \\
\hline $0.416-3.96$ & & Variation & {$[52]$} & Koopmans and Koppejan, 1997 $\square$ & [49]+ various older refs. \\
\hline $1.1-2.9$ & & Variations & {$[53]$} & Ryan and Openshaw, 1991 $\square$ & \\
\hline $0.81-2.29$ & & California & {$[40]$} & Summers et al., $2003 \square$ & Measurements \\
\hline 1.27 & $10 \mathrm{~cm}$ & California & {$[40]$} & Summers et al., 2003 $\square$ & Measurements \\
\hline 0.447 & high & Thailand & {$[41]$} & Bhattacharya et al., $1989 \square$ & Measurements \\
\hline 0.447 & & Thailand & {$[50]$} & Sajjakulnukit et al., 2005 $\square$ & {$[41]$} \\
\hline 0.447 & & Thailand & {$[54]$} & Prasertsan and Sajjakulnukit, 2006 & Sajjakulnukit 2001 --n.a. \\
\hline 0.60 & & Thailand & {$[55]$} & Delivand et al., 2011 $\square$ & {$[2],[50],[56]$} \\
\hline 0.75 & & $\begin{array}{l}\text { India, } \\
\text { Thailand, } \\
\text { Philippines }\end{array}$ & [2] & Gadde et al., 2009 $\square$ & {$[57]$} \\
\hline 0.96 & & Japan & {$[58]$} & Matsumura et al., 2005 $\square$ & \\
\hline 1.43 & & Egypt & {$[16]$} & Said et al., $2013 \square$ & [59] \\
\hline $1.0-2.0$ & & Variations & {$[60]$} & Fischer et al., 2007 $\square$ & {$[52]$} \\
\hline 1.5 & & Global & [34] & Eisentraut, 2010 $\square$ & {$[60][52]$} \\
\hline 1.5 & & Ghana & [19] & Duku et al., $2011 \square$ & [34] \\
\hline 1.5 & & Ghana & {$[14]$} & Mohammed et al., 2013 $\square$ & [19] \\
\hline 1.5 & & Cameroun & {$[15]$} & Ackom et al., 2013 $\square$ & [19] \\
\hline 1.5 & & SSA & [9] & Dasappa, 2011 $\square$ & {$[61]$} \\
\hline 1.66 & & Ghana & {$[13]$} & Kemausuor et al., $2014 \square$ & [19], \\
\hline 1.695 & $5 \mathrm{~cm}$ & Thailand & [41] & Bhattacharya et al., $1989 \square$ & Measurement \\
\hline 1.695 & & Thailand & {$[56]$} & Yokoyama et al., $2000 \square$ & {$[41]$} \\
\hline 1.757 & & Thailand & [49] & Bhattacharya et al., 1993 & {$[41]$} \\
\hline 1.757 & & S. E. Asia & {$[52]$} & Koopmans and Koppejan, 1997 $\square$ & [49] \\
\hline 1.757 & & Nigeria & [12] & Iye and Bilsborrow, 2013 $\square$ & {$[52]$} \\
\hline 1.757 & & Nigeria & {$[11]$} & Simonyan and Fasina, 2013 $\square$ & {$[52]$} \\
\hline 1.76 & & Sri Lanka & {$[51]$} & Perera et al., 2005 $\square$ & [49] \\
\hline 2.07 & & SSA & [10] & Cooper and Laing, 2007 & [52] \\
\hline
\end{tabular}

What is noteworthy, however, is that most of the other references also refer directly or indirectly back to these measurements from Bhattacharya et al. [41].

To introduce an example from SSA, the twostudies from Ghana and one from Cameroon [13] [14] and [15], which suggest a RPR of 1.5-1.66 all indirectly refer back to Bhattacharya's high value. More precisely, they refer back to Duku et al.[19], 
who is referring back to Eisentraut [34]. Eisentraut uses the value of 1.5 based on three sources:

i) Koopmans and Koppejan [52], who find a large variety of RPRs in the range of 0.416-3.96 based on a number of sources in the period from 1979-1991, but who nevertheless ends up using a RPR of 1.75 for Southeast Asia, based on the low cutting height value reported in [49].

ii) Fischer et al. [60], who deal with biomass in Europe, and who only provide an interval between 1 and 2. One can guess that the value of 1.5 is based on the mean of this interval. Fischer is referring to: a) Koopmans and Koppejan [52] (referring back to Bhattacharya), b) Ryan and Oppenshaw[53], who only provide a broad range (1.1-2.9) based on [62] and, c) to [63], who again refers back to Koopmans and Koppejan (and Bhattacharya).

iii) A general reference to proceedings from an OECD conference on biomass, OECD (2004), comprising various papers on biomass activities and biomass policies, and not presenting original research on RPRs.

What we see here is a long chain of almost circular references to desk studies referring to other desk studies. With regard to original studies, many of these point back to measurements made by Bhattacharya in 1989 [41], and again referred to in 1993 [49]. It is noteworthy that from the scientific point of view the data in the 1989 paper remains uncertain as a number of factors such as soil conditions, fertilizer input, the selection of samples and the number of samples are not described.

The most detailed and best documented research available was conducted in California [40]. This research shows high variability of RPR depending on variety, fertilizer input and yield, from 0.81-2.27 with a mean of 1.27 . This value, which is based on a low cutting of straw (10 cm above ground), is valid for industrialised countries with high-yielding farming practices, but it is still substantially lower than the 1.5 and 1.757 used by Bhattacharya for Thailand in 1993.

The discussion above shows that there is considerable uncertainty regarding RPRs and that there is a strong need for more rigorous scientific measurements of the RPR for rice straw, including current varieties in developing countries and involving all the relevant parameters. In our model we used an RPR of 0.75 , based on information from the local research institute, and taking into consideration the practice of harvesting with a sickle, which cuts the straw relatively high. This farming practice may change due to mechanisation or to increased demand for straw for energy, and therefore we have used the value of 1.5, reflecting an optimistic scenario. Importantly, the uncertainty regarding RPRs implies that the available resource may double in the optimistic scenario due to this parameter alone. 


\subsection{Availability factor}

Uncertainly regarding the availability factor is also high, though the interval of this parameter may double the available resource in the optimistic scenario. This is firstly because it remains unclear to what extent it is environmentally sustainable to use the straw already incorporated into the ground for biomass use. The base scenarios therefore represent the situation where only straw currently burned is included (15\%), while the optimistic scenario includes straw burned as well as straw incorporated into the ground (30\%).

Secondly, there will be relatively high uncertainty regarding the estimates for the use of straw in the different use categories, even though this was given the highest priority in this study, including 263 interview-based questionnaires. The reasons for this uncertainty are mainly related to the sampling (representativeness of the interviewees), the interviewees' understanding of the questions, but just as importantly on the interviewer's bias in terms of his understanding of the questions, his way of posing them, his position in relation to the interviewees, and the risk of strategic answers.

In the original plan, the interviews were to be conducted by a small group of three to five interviewers local to the interview area, who were to be contracted for this specific job on a day to day basis. Furthermore, it was envisaged conducting the interviews based on a randomised sampling of the farmers in the area, and to document the geographical spread by using a GPS for the interviews.

However, due to a number of constraints that emerged during the fieldwork, the main stratification criteria became scales of production based on last year's production data and a geographical spread. No tests have been conducted for representativeness with respect to the size of farms, income levels, educational levels or ethnicity, but no signs of such bias were found. More seriously, instead of various interviewers per zone, the zone of Macina was divided between two interviewers, while each of the zones close to Niono (Niono, N'debougou, Molodo) were covered by just one interviewer. Furthermore, instead of being independent of the ON extension services, all the interviewers turned out to be related to them.

The relatively high variation in straw burned in the field in the three zones around Niono (22\%, 19\%, 12\%) and the straw incorporated into the soil (11\%, 10\% and 7\%) could therefore to some degree reflect interviewer bias with regard to how the questions were posed and how the answers were interpreted. In this case there might also be a bias due to the power relationship between the interviewer (the extension officer) and the farmer. The reports of a relatively low level of straw being burned in the field could be influenced by the fact that extension services have campaigned for years against burning in the field. Both effects of interviewer bias are exemplified by the fact that the first analysis of data showed that in the zone of Niono only $1 \%$ of the straw was burned, while the two adjacent zones showed $19 \%$ and $12 \%$. As there were 
no good reasons for this divergence, the field study manager later conducted twenty control interviews in the zone and came up with a result of $22 \%$ instead of $1 \%$. Interviews during the second period of fieldwork also revealed that the interviewer was known to oppose burning straw in the field. As this finding was more in line with the results from the adjacent zones, the results of these twenty control interviews have been used in the final result. This experience, however, illustrated the level of uncertainty, as well as the fact that the $15 \%$ used as a mean value may be slightly underestimated.

\section{Implications for studies of lignocellulosic residues in SSA}

The results of the assessment presented in the last section raise a number of questions which have implications for resource assessments for lignocellulosic residues in other African countries. First, when reviewing the literature, the lack of a common terminology for the availability of resources and the confusion this may create are remarkable. Secondly, it is also remarkable that only about $15 \%$ of the straw is available for energy purposes in ON, despite its exceptionally high concentration of rice straw. This raises the question of availability in other parts of Mali with lower concentrations and higher pressures from cattle, as well as about the actual availability factors used in other country studies. Thirdly, the case study uncovered a high level of uncertainty regarding the input parameters to the model, which led to high uncertainty regarding the sustainability of the resource at present, and not least in the near future. This raises the more general question of the level of uncertainty in similar resource assessments in SSA.

\subsection{Methodology and terminology}

The review of studies of lignocellulosic biomass resources in SSA shows that there is confusion over the terminology when referring to resources. A number of studies acknowledge and refer to the widespread terminology describing resources in terms of their theoretical potential, technical potential, economic potential and implementation potential [7].

The studies referred to all use the same method for calculating the potential (production of grain * RPR), but the result is called theoretical potential and technical potential interchangeably. Most studies acknowledge that not all biomass can be used for energy, but some studies do not address this issue specifically. Most studies, however, include an availability ratio or a recovery factor, which can be defined according to competing use for, e.g., fodder, economic considerations (that it is not possible to collect dispersed quantities for energy) and ecological considerations, e.g., the need for carbon stock in the ground or based on implementation constraints. Most 
often there is a mixture of arguments, and as the result falls somewhere in between the categories of economic potential, implementation potential, environmental potential and sustainable potential, they are not comparable. (For an overview of terminology, see Table 6.1.) Unfortunately, this is not specific to studies of biomass resources in SSA, but is part of a general practice. In a recent review of biomass resource studies in Europe, Bentsen and Felby [8] note that 'variability and methodological inconsistency seem to overrule the theory'.

\subsection{Availability factors}

In recent studies from SSA there is a high variation in the availability factor or recovery factor used (see Table 6.1). Dasappa [9] uses 30\% in a global study of SubSaharan Africa. Said et al. [16] use 100\% for Egypt, Simonyan and Fasina [11] 100\% for Nigeria. Iye and Bilsborrow [12] describe three scenarios for Nigeria: one with $100 \%$ availability; a second 'realistic' scenario where $55 \%$ is available for energy while $35 \%$ is used for soil improvement and grazing and $10 \%$ for animal feed and bedding; and a third scenario in which $27.5 \%$ is available for energy. In a review article, Duku et al. [19] do not specify a availability rate, but concludes that "rice husk and straw are virtually unutilised and could serve as a major source of energy in Ghana”. Also for Ghana, but conversely, Kemausuor et al. [13] use 25\% to calculate the 'technical potential' based on Smeets [64], while Ackom et al. [15] use 20\% as the 'sustainable fraction' for Cameroon, referring to Eisentraut [34].

Common to all studies is that the availability factors used are not based on empirical research in the countries concerned, but are rather rough assumptions based on literature covering other countries and regions. For example, the two cases of $100 \%$ availability are based on rice production in the US [59], while the $25 \%$ and $20 \%$ variants are based on the global studies [64] and [34].

There seem to have been a certain consensus for using a 25\% availability factor in global studies $[7,34,65]$. Based on input from local consultants who were responsible for country studies, Eisentraut [34] introduced two scenarios using 10\% and 25\% respectively. In one passage he even tends to recommend using $25 \%$ for developed countries and $10 \%$ for developing countries, mainly due to the higher demand for cattlefeed in developing countries.

This paper supports this recommendation based on the following argument. The case study presented is an extreme one, in which we would expect the highest availability factor [66]. This is because ON is by far the largest and most intensively cultivated area, where about $25 \%$ of Mali's total rice crop is produced. The availability factor is expected to be high because rice is produced in a large coherent irrigation scheme, with relatively low cattle pressure due to its size and with high yields of about 6 tons per ha. This is in contrast to the other localities, where $75 \%$ of Malian rice is produced 
on relatively dispersed rain-fed or indirectly irrigated fields with higher cattle pressure and lower yields of 1-2 tons per ha [37,39].

In spite of these 'extreme' conditions, only about $15 \%$ of the straw in ON is considered to be available for the sustainable use for energy, mainly due to competing use for cattle feed. In other areas of Mali, where yields are much lower, areas and fields of rice cultivation are dispersed, and the pressure for cattle-feed is higher, there being only a little if any potential for the sustainable use of straw for energy purposes. An indication of this is that, according to the survey, only $2 \%$ of straw was burned in Macina, which is located on the boundaries of ON, while this share was $15-18 \%$ at the centre.

If as a simple example we consider $15 \%$ availability for $25 \%$ of production and $0 \%$ availability for $75 \%$ of production, the average availability factor is about $4 \%$. This estimate is firstly not solidly grounded empirically, and secondly conditions in Mali are different than in other SSA countries. While still practiced in most parts of West Africa, the traditional system of Fulani herders grazing their cattle on harvested fields is especially important in the north and centre of Mali [27,28]. This may to some extent explain the lower availability factor found in this study compared to other studies in SSA, but given the lack of empirical studies of the actual use of rice straw, the findings still support Eisentraut's proposal that the availability factor be lowered to $10 \%$ in SSA, due to competing uses for fodder and soil improvements.

Given that none of the studies mentioned above are based on empirical studies of competing uses of straw, there is a strong need for more and better empirical studies of competing uses of lignocellulosic biofuels in Africa. Until such studies are carried out, the modest contribution of this article should stant as a warning that existing studies of rice straw or other agricultural residue streams seriously overestimate the potential based on the values of the availability factor alone.

\subsection{Level of uncertainty}

The case study in this paper uncovered a high degree of uncertainty regarding the input parameters to the model: yield, RPR, land-use change and availability factor. This led to a high level of uncertainty regarding estimates of sustainable resources. One important factor was the time factor and the expected change in land use and yield within the period from 2012 to 2020 . This alone doubled the resource compared to the BAU. On top of that, a more optimistic expectation regarding each of the factors - yield, land used for rice, RPR and availability - increased the potential by a factor $1.14,1.48,2.0$ and 2.0 respectively compared to the realistic scenario. This is an important finding, and it has implications for the other studies of lignocellulosic residues in Africa listed in Table 6.1. None of these studies discuss the level of uncertainties, except for the availability factor discussed above. Most importantly, all 
the studies provide static representations, which do not take into consideration any future developments. They are also based on actual production figures for rice based mainly on statistics from the FAO, and none of them discuss future increases in yields and changes to land use. In addition, none of them discuss the RPR in relation to either yield or harvesting practices, which this article has shown is essential (see Table 5.1). These issues, alongside the uncertainty regarding the availability factor discussed above, indicates that there is a high risk that studies of 'available' or 'sustainable' biomass potentials at the country level are being seriously overestimated. This article therefore calls for more empirical research on specific crops and on specific farming conditions. 
Table 6.1. Overview of essential parameters in recent studies including potentials for rice straw in Africa,

\begin{tabular}{|c|c|c|c|c|c|c|}
\hline Concept & $\begin{array}{l}\text { Yield } \\
\text { tonnes/ha }\end{array}$ & $\begin{array}{l}\text { Straw-to- } \\
\text { grain ratio }\end{array}$ & $\begin{array}{l}\text { Availability } \\
\text { ratio/recoverability } \\
\text { fraction }\end{array}$ & $\begin{array}{l}\text { Scenario } \\
\text { in time }\end{array}$ & $\begin{array}{l}\text { Country/ } \\
\text { region }\end{array}$ & Source \\
\hline $\begin{array}{l}\text { Technical } \\
\text { potential/availability }\end{array}$ & n.a. & 1.5 & $\begin{array}{l}\text { 25\% developed } \\
10 \% \text { developing }\end{array}$ & 2030 & Global & {$[34]$} \\
\hline Technical potential & n.a. & n.a. & $25 \%$ & 2050 & Global & {$[64,65]$} \\
\hline $\begin{array}{l}\text { Potential/available } \\
\text { ressource }\end{array}$ & n.a. & 1.5 & $30 \%$ & Actual & SSA & [9] \\
\hline $\begin{array}{l}\text { Potential energy } \\
\text { source }\end{array}$ & n.a. & $\begin{array}{l}2.07 \text { avr. } \\
(1.4-3.28)\end{array}$ & $\begin{array}{l}\text { n.a. , } 35 \% \\
\text { mentioned }\end{array}$ & Actual & SSA & {$[10]$} \\
\hline $\begin{array}{l}\text { Theoretical/collectable } \\
\text { ressource }\end{array}$ & n.a. & 1.43 & $100 \%$ & Actual & Egypt & {$[16]$} \\
\hline $\begin{array}{l}\text { Potential/Sustainable } \\
\text { potential }\end{array}$ & n.a. & 1.5 & $20 \%$ & Actual & Cameroun & {$[15]$} \\
\hline Potential ressource & 2.0 & 1.5 & $\begin{array}{l}\text { high potential, } \\
\text { virtually unused, } \\
\text { In practice not all } \\
\text { can be collected. }\end{array}$ & Actual & Ghana & [19] \\
\hline Theoretical potential & n.a. & 1.5 & n.a. & Actual & Ghana & {$[14]$} \\
\hline $\begin{array}{l}\text { Theoretical/technical } \\
\text { potential }\end{array}$ & n.a. & 1.66 & $25 \%$ & Actual & Ghana & {$[13]$} \\
\hline $\begin{array}{l}\text { Potential/Available } \\
\text { ressource }\end{array}$ & 2.0 & 1.757 & $100,55,27.5 \%$ & Actual & Nigeria & {$[12]$} \\
\hline Potential ressource & 1.84 & 1.757 & $100 \%$ & Actual & Nigeria & [11] \\
\hline
\end{tabular}

\section{Conclusion}

This article puts forward three main conclusions. First, rice straw has sustainable potential for energy in Mali. The main potential is situated in the intensively farmed rice area in ON, where about 120,000 tons of straw is expected to be available for energy use in 2020. This may fuel up to three power plants of five MW.

Secondly, the empirical research documents the high degree of uncertainty that exists regarding the sustainable resources of straw. Depending on variation of the major parameters, the sustainable resource in ON may vary from 56,000 tons up to 800,000 tons. The main uncertainties are related to increases in the area under rice, the RPR, and the definition of the availability rate for sustainability.

Thirdly, the article finds that recently published research on biomass potential in Africa that includes rice straw is characterized by: i) variability and methodological inconsistency with regard to concepts for resource potentials; ii) overestimates of availability factors, not paying sufficient attention to the impact of resources being spread over large areas, and the amount being used for cattlefeed and soil amendment; 
and iii) a failure to address the static nature of such studies and the high level of uncertainty regarding their results.

\section{Acknowledgement}

The authors wish to acknowledge the support from the Danish development cooperation, DANIDA, for funding part of this study (Danida contract 1711). Special thanks to two anonomous reviewers and to Emmanuel Ackom, UNEP DTU Partnership for providing valuable comments to an earlier version of this article. 


\section{References}

[1] Suramaythangkoor T, Gheewala SH. Potential of practical implementation of rice straw-based power generation in Thailand. Energy Policy 2008;36:3193-7.

[2] Gadde B, Menke C, Wassmann R. Rice straw as a renewable energy source in India, Thailand, and the Philippines: Overall potential and limitations for energy contribution and greenhouse gas mitigation. Biomass and Bioenergy 2009;33:1532-46.

[3] Fock F, Nygaard I, Maiga A, Kone B, Kamissoko F, Coulibali N, et al. Prefeasibility study for an electric power plant based on rice straw. UNEP Risø Centre, Technical University of Denmark. 2012. Available from: www.frsemali.org, [accessed 5. June 2015]

[4] Binod P, Sindhu R, Singhania RR, Vikram S, Devi L, Nagalakshmi S, et al. Bioethanol production from rice straw: An overview. Bioresour Technol 2010:4767-74.

[5] Srirangan K, Akawi L, Moo-Young M, Chou CP. Towards sustainable production of clean energy carriers from biomass resources. Appl Energy 2012;100:172-86.

[6] Thrän D, Seidenberger T, Zeddies J., Offermann R. Global biomass potentials — Resources, drivers and scenario results. Energy Sustain Dev 2010;14:200-5.

[7] Berndes G, Hoogwijk M, van den Broek R. The contribution of biomass in the future global energy supply: a review of 17 studies. Biomass and Bioenergy 2003;25:1-28.

[8] Bentsen N, Felby C. Biomass for energy in the European Union - a review of bioenergy resource assessments. Biotechnol Biofuels 2012;5:1-25.

[9] Dasappa S. Potential of biomass energy for electricity generation in subSaharan Africa. Energy Sustain Dev 2011;15:203-13.

[10] Cooper CJ, Laing CA. A macro analysis of crop residue and animal wastes as a potential energy source in Africa. J Energy South Africa 2007;18:10-9.

[11] Simonyan KJ, Fasina O. Biomass resources and bioenergy potentials in Nigeria. African J Agric Res 2013;8:4975-89.

[12] Iye EL, Bilsborrow PE. Assessment of the availability of agricultural residues on a zonal basis for medium- to large-scale bioenergy production in Nigeria. Biomass and Bioenergy 2013;48:66-74.

[13] Kemausuor F, Kamp A, Thomsen ST, Bensah EC, Østergård H. Assessment of biomass residue availability and bioenergy yields in Ghana. Resour Conserv Recycl 2014;86:28-37. 
[14] Mohammed YS, Mokhtar AS, Bashir N, Saidur R. An overview of agricultural biomass for decentralized rural energy in Ghana. Renew Sustain Energy Rev 2013;20:15-25.

[15] Ackom EK, Alemagi D, Ackom NB, Minang PA, Tchoundjeu Z. Modern bioenergy from agricultural and forestry residues in Cameroon: Potential, challenges and the way forward. Energy Policy 2013;63:101-13.

[16] Said N, El-Shatoury SA, Díaz LF, Zamorano M. Quantitative appraisal of biomass resources and their energy potential in Egypt. Renew Sustain Energy Rev 2013;24:84-91.

[17] Jingura RM, Matengaifa R. The potential for energy production from crop residues in Zimbabwe. Biomass and Bioenergy 2008;32:1287-92.

[18] Batidzirai B, Faaij APC, Smeets E. Biomass and bioenergy supply from Mozambique. Energy Sustain Dev 2006;x:54-81.

[19] Duku MH, Gu S, Hagan E Ben. A comprehensive review of biomass resources and biofuels potential in Ghana. Renew Sustain Energy Rev 2011;15:404-15.

[20] Schreyger E. La période 1032-1982. In: Kuper M, Tonneau J-P, editors. L’Office du Niger, grenier à riz du Mali Succès économiques, transitions Cult. Polit. Dev., Paris: Karthala; 2001, p. 68-74.

[21] Slob A. Le rôle des bailleurs de fonds. In: Kuper M, Tonneau J-P, editors. L’Office du Niger, grenier à riz du Mali Succès économiques, transitions Cult. Polit. Dev., Paris: Karthala; 2001, p. 97-9.

[22] Tall EHO. La restructuration de l'Office du Niger. In: Kuper M, Tonneau J-P, editors. L’Office du Niger, grenier à riz du Mali Succès économiques, transitions Cult. Polit. Dev., Paris: Karthala; 2001, p. 93-6.

[23] Brondeau F. L’agrobusiness á l'assaut des terres irriguées de l'office du Niger (Mali). Cah Agric 2011;20:136-43.

[24] Baxter J. Understanding land investments in Africa. Country report: Mali. 2011. Available from: http://allafrica.com/download/resource/main/main/idatcs/00021029:0d0f31641 207deae38bb314ff8a1bccd.pdf: The Oakland Institute, [accessed 19.01.16].

[25] Vandersypen K, Keita ACT, Coulibaly B, Raes D, Jamin JY. Drainage problems in the rice schemes of the Office du Niger (Mali) in relation to water management. Agric Water Manag 2007;89:153-60.

[26] Le Masson A, Sangaré Y, Ducrot R. Le rôle de l'élevage dans l'intensification: Le bétail, outil de travail et source de fumure. In: Kuper M, Tonneau J-P, editors. Off. Niger, grenier à riz du Mali Succes Econ. transitions Cult. Polit. Dev., Paris: Karthala; 2001, p. 125-6.

[27] Oksen P. Cattle, Conflicts and Change: Animal Husbandry and Fulani Farmer Interactions in Boulgou Province, Burkina Faso. Roskilde University, 2000 . 
[28] Benjaminsen T.A, Ba B. Farmer-herder conflicts, pastoral marginalisation and corruption: a case study from the inland Niger delta of Mali. Geogr J 2009;175:71-81.

[29] Turner MD. Political ecology and the moral dimensions of "resource conflicts": the case of farmer-herder conflicts in the Sahel. Polit Geogr 2004;23:863-89.

[30] Nygaard I, Rasmussen K, Badger J, Nielsen TT, Hansen LB, Stisen S, et al. Using modeling, satellite images and existing global datasets for rapid preliminary assessments of renewable energy resources: The case of Mali. Renew Sustain Energy Rev 2010;14:2359-71.

[31] Badger J, Larsen S, Rasmussen K, Nielsen TT, Hansen LB, Mariko A, et al. Renewable Energy Resources in Mali: Preliminary mapping. Risø DTU, National Laboratory for Sustainable Energy; 2008, Available at: http://orbit.dtu.dk/getResource?recordId=233356\&objectId=1\&versionId=1: [accessed 19.01.16]

[32] Togola I. Usage de la biomass à partir de déchets agro-industriels. Presentation par Mali Folkcenter à l'atelier de concertation, Bakako 07 mars 2008; 2008.

[33] Fofana TA. Déchets de biomasse à partir d'agro-industrie. Presentation par CNESOLER á l'atelier de concertation 07 Mars 2008; 2008.

[34] Eisentraut A. Sustainable production of second-generation biofuels, potential and perspectives in major economies and developing countries. Information paper. 2010 Available from: http://utias.utoronto.ca/ ogulder/X_second_generation_biofuelsIEA2010.pdf: IEA Renewable Energy Division, [accessed 19.01.16].

[35] Rettenmaier N, Reinhardt G, Schorb A, Köppen S, Falkenstein E von. Biomass Energy Europe. Status of Biomass Resource Assessments Version 1. Biomass Energy Europe; 2008.

[36] Batidzirai B, Smeets EMW, Faaij APC. Harmonising bioenergy resource potentials: Methodological lessons from review of state of the art bioenergy potential assessments. Renew Sustain Energy Rev 2012;16:6598-630.

[37] Nygaard I, Bruun TB, Traoré OF, Dembelé F, Borgstrøm R, Dao I, et al. Agricultural residues for energy production in Mali. UNEP Risø Centre, Technical University of Denmark; 2012, Available from: www.frsemali.org [accessed 19.01.16]

[38] Aw D, Diemer G. Making a large irrigation scheme work: A case study from Mali. Washington: World Bank; 2005.

[39] MA. Stratégie nationale de developpement de la riziculture. Ministére de l'agriculture, Republique du Mali; 2009. Available at: http://www.jica.go.jp/english/operations/thematic_issues/agricultural/pdf/mali_ fr.pdf, [assessed 19.01.16] 
[40] Summers MD, Jenkins BM, Hyde PR, Williams JF, Mutters RG, Scardacci $\mathrm{SC}$, et al. Biomass production and allocation in rice with implications for straw harvesting and utilization. Biomass and Bioenergy 2003;24:163-73.

[41] Bhattacharya SC, Shrestha RM, Ngamkajornvivat S. Potential of Biomass Residue Availability: The Case of Thailand. Energy Sources 1989;11:201-16.

[42] Zwarts L, Kone B. Rice production in the inner Niger delta. In: Zwarts L, van Beukering P, Kone B, Wymenga E, editors. Niger, a lifeline. Eff. water Manag. Up. Niger Basin, Mali / the Netherlands: RIZA, Lelystad / Wetlands International, Sévaré / Institute for Environmental studies (IVM), Amsterdam / A\&W ecological consultants, Veenwouden.; 2005, p. 137-53.

[43] Wymenga E, van der Kamp J, Fofona B. The irrigation zone of Office de Niger. In: Zwarts L, van Beukering P, Kone B, Wymenga E, editors. Niger, a lifeline. Eff. water Manag. Up. Niger Basin, Mali / the Netherlands: RIZA, Lelystad / Wetlands International, Sévaré / Institute for Environmental studies (IVM), Amsterdam / A\&W ecological consultants, Veenwouden.; 2005, p. 179-87.

[44] Vandersypen K, Bengaly K, Keita ACT, Sidibe S, Raes D, Jamin JY. Irrigation performance at tertiary level in the rice schemes of the Office du Niger (Mali): Adequate water delivery through over-supply. Agric Water Manag 2006;83:144-52.

[45] Vandersypen K. Improvement of collective water management in the Office du Niger irrigation scheme (Mali). Development of decision support tools. PhD thesis Katholieke Universiteit Leuven, 2007.

[46] Hydro-PACTE. Le bases de l'operationnalisations: point d'execution du SDDZON sur la periode 2005-2009: Presentation no. 2. Presentation at Forum sur l’Office du Niger, 19 Avril 2010; 2010.

[47] AGETIER. Etude du Schéma Directeur de Développement pour la Zone de l’Office du Niger (Etape Finale): Document 2a, Plan d'action. Segou, Mali: Agence d'Exécution des Travaux d'Infrastructures et d'Equipements Ruraux (AGETIER) MALI, Consultants for Development Programmes, (CDP); 2004.

[48] Bøås M, Torheim LE. The Trouble in Mali: Corruption, collusion, resistance. Third World Q 2013;34:1279-92.

[49] Bhattacharya SC, Pham HL, Shrestha RM, Vu Q V. CO2 emissions due to fossil and traditional fuels, residues and wastes in Asia. AIT Workshop on Global Warming Issues in Asia, 8-10 September 1992, AIT, Bangkok, Thailand: 1993.

[50] Sajjakulnukit B, Yingyuad R, Maneekhao V, Pongnarintasut V, Bhattacharya SC, bdul Salam P. Assessment of sustainable energy potential of nonplantation biomass resources in Thailand. Biomass and Bioenergy 2005;29:214-24.

[51] Perera KKCK, Rathnasiri PG, Senarath SAS, Sugathapala AGT, Bhattacharya SC, bdul Salam P. Assessment of sustainable energy potential of non- 
plantation biomass resources in Sri Lanka. Biomass and Bioenergy 2005;29:199-213.

[52] Koopmans A, Koppejan J. Agricultural and forest residues - generation, utilization and availability. Paper Presented at the Regional Consultation on Modern Applications of Biomass Energy, 6-10 January 1997, Kuala Lumpur, Malaysia: FAO; 1997.

[53] Ryan P, Openshaw K. Assessment of Biomass Energy Resources : A Discussion on its Need and Methodology. Washington D. C.: Energy Series Paper No. 48, World Bank; 1991.

[54] Prasertsan S, Sajjakulnukit B. Biomass and biogas energy in Thailand: Potential, opportunity and barriers. Renew Energy 2006;31:599-610.

[55] Delivand MK, Barz M, Gheewala SH. Logistics cost analysis of rice straw for biomass power generation in Thailand. Energy 2011;36:1435-41.

[56] Yokoyama S, Ogi T, Nalampoon A. Biomass energy potential in Thailand. Biomass and Bioenergy 2000;18:405-10.

[57] Gadde B, Menke C, Wassmann R. Possible energy utilization of rice straw in Thailand: seasonal and spatial variations in straw availability as well as potential reduction in greenhouse gas emissions. GMSARN international conference on sustainable development: challenges and opportunities for GMS. Pattaya (Thailand), AIT 2007; 2007.

[58] Matsumura Y, Minowa T, Yamamoto H. Amount, availability, and potential use of rice straw (agricultural residue) biomass as an energy resource in Japan. Biomass and Bioenergy 2005;29:347-54.

[59] Klass DL. Biomass for Renewable Energy, Fuels, and Chemicals. San Diego: Academic Press; 1998.

[60] Fischer G, Hizsnyik E, Prieler S, Velthuizen H Van. Assessment of biomass potentials for bio- fuel feedstock production in Europe : Methodology and results. Refuel program, July 2007; 2007.

[61] CGLP. Combustion, gasification and propulsion laboratory. Indian Institute of Science, Bangalore 560 012, India, 2011. Available at: http://cgpl.iisc.ernet.in, [assessed 19.01.16]

[62] Barnard G, Kristoferson L. Agricultural Residues as Fuel in the Third World. London: Earthscan; 1985.

[63] Jölli D, Giljum S. Unused biomass extraction in agriculture , forestry and fishery. Vienna, Austria: Sustainable Europe Research Institute (SERI); 2005.

[64] Smeets EMW. A quickscan of global bioenergy potentials to 2050. An analysis of the regional availability of biomass resources for export in relation to the underlying factors. Netherlands, 2004, Available at: http://www.riaed.net/IMG/pdf/A_quickscan_of_global_bioenergy_potentials_t o_2050.pdf: Utrecht University, [accessed 19.01.16] 
[65] Smeets EMW, Faaij APC, Lewandowski IM, Turkenburg WC. A bottom-up assessment and review of global bio-energy potentials to 2050. Prog Energy Combust Sci 2007;33:56-106.

[66] Flyvbjerg B. Five misunderstandings about case-study research. Department of Development and Planning, Aalborg University; 2004. 